\title{
Adoption of International Public Sector Accounting Standards in Public Sector of Developing Economies -Analysis of Five South Asian Countries
}

\author{
Zhuquan Wang ${ }^{1} \&$ Javed Miraj $^{1,2}$ \\ ${ }^{1}$ College of Management, Ocean University of China, Qingdao, China \\ ${ }^{2}$ Lasbela University of Agriculture, Water and Marine Science, Uthal, Balochistan, Pakistan \\ Correspondence: Professor Zhuquan Wang, College of Management, Ocean University of China, Qingdao, China.
}

Received: December 18, 2018

doi:10.5430/rwe.v9n2p44
Accepted: December 26, 2018

Online Published: December 27, 2018

URL: https://doi.org/10.5430/rwe.v9n2p44

\begin{abstract}
We examined the extent of adoption of the International Public Sector Accounting Standards (IPSAS) in South Asia and the challenges that are decelerating this process. The moderating organization, International Public Sector Accounting Standards Board (IPSAB), instituted IPSAS in an effort to improve financial reporting by public sector organizations and for comparability purposes. The aims of this research were to establish to what extent the IPSAS has been adopted in South Asia and determine the drawbacks contributing to its slow adoption process. To answer the study questions a literature review of the South Asian countries that have adopted the IPSAS was conducted. The study findings show that most of the South Asian nations have adopted the IPSASs though to different extents. Nepal, Bangladesh, Pakistan and Sri Lanka have implemented the IPSAS but taking different approaches and directions, while India still uses the cash based accounting system. The key barriers include; lack of experienced staff, delay in provision of information by the public entities, and lack of a defined implementation timeframe which seem to cut across these countries.
\end{abstract}

Keywords: IPSAS, public sector, India, Pakistan, Bangladesh, Nepal, Sri Lanka

\section{Introduction}

International Public Sector Accounting Standards (IPSAS), the equivalent of international financial reporting standards (IFRS) that govern financial accounting in the private business entities, are steadily gaining implementation momentum in public sector accounting over the past 10 years. The IPSASs regulates financial accounting processes of government sectors excluding profit making public firms (Ijeoma and Oghoghomeh, 2014). Globally, more than 40 government sectors have adopted the revised standards (ACCA, 2018). The motivation for application of the standards in public sector is their ability to provide a more transparent and accurate financial overview of firms listed in the Stock Exchange with the implication being a radical change in practice of financial reporting and easy comparability (Brusca, Caperchione, Cohen, and Rossi, 2016). More importantly, the need for globalization, easy in management of international trade and implementation of joint international development projects requires comparable and similar financial accounting standards. This is because practice and implementation of the standards greatly varies between nations in terms of structure; cash-basis or accrual-based financial disclosure.

Public sector organizations are tasked with the provision of services to the general public in any given country and they should ensure equal distribution of resources. They are owned by the governments hence are public entities financed by taxes from other sectors (Kara, 2012). Accounting procedures in these entities entails collection, recording, grouping and summarizing of financial reports and statements of all financial events taking place in these institutions. The financial reports and statements are then communicated in a transparent and accountable manner to the public and other associated consumers (Kara, 2012).

Lower (LICs) and middle (MICs) income countries especially in Asia and Africa experience a series of crises resulting to accrual of large public debts. On the hand, privately managed business enterprises in the same countries are thriving well. Partially this can be attributed to the poor management of the public funds. Most of these countries use cash based financial accounting system which presents with a lot disparities across entities and even within the same organization, hence not comparable. Adopting and implementing IPSASs will provide a solution to ensure consistence, and comparability is attained. 
A study by Adhikari and Mellemvick (2010) established that majority of the South Asian nations have envisaged the espousal of the cash basis IPSAS principles in an effort to implement the accrual accounting method. Most of these countries are geared towards adapting rather than adopt the standards in all material aspects. This study seeks to analyze the adoption of IPSAS in five South Asian counties namely, Bangladesh, India, Nepal, Pakistan and Sri Lanka and explore the challenges in implementation of the standards. Through a literature review, we report the extent of adoption of IPSASs, and the barriers that are slowing down the process. The study therefore fills the knowledge gap using a regional approach rather than a country approach.

\section{Research Methodology}

The research was conducted through the application of a literature review design. According to Yegidis, Weinbach, and Myers (2017), a literature review provides comprehensive insights about the topic under evaluation and is essential for development of current literature. Different views of authors on the subject are offered thus making it easier to answer the question under investigation. Obtained results are more accurate than in individual studies which are prone to bias. Due to the logistical issue of covering long distances over a small period, it is efficient to use the already existing literature.

A literature search was carried out in Google scholar using "International Public Sector Accounting Standards" or "IPSAS" or "IPSASs" and "South Asia", "India", "Bangladesh", "Sri Lanka", "Afghanistan", "Bhutan", "Nepal", "Pakistan" and "Maldives" as search terms. Nine articles were retrieved and used in the study.

\section{Results}

Table 1. Articles retrieved from Google for the review

\begin{tabular}{|c|c|c|}
\hline Article & Year of publication & Study Finding \\
\hline \multirow[t]{2}{*}{ Krishnan } & 2016 & $\begin{array}{l}\text { The Indian government's business entities are still using a } \\
\text { cash based public accounting system. }\end{array}$ \\
\hline & & $\begin{array}{l}\text { The government is yet to set time frames for adoption and } \\
\text { implementation of IPSASs. }\end{array}$ \\
\hline Ombati and Shukla & 2018 & $\begin{array}{l}\text { The Indian government entities are still using a cash based } \\
\text { public accounting standard. }\end{array}$ \\
\hline \multirow[t]{2}{*}{ Adhikari } & 2017 & $\begin{array}{l}\text { The Nepal Accounting Standards Board drafted and } \\
\text { published the Nepal Public Sector Accounting Standards } \\
\text { (NPSAS). }\end{array}$ \\
\hline & & No accrual to IPSASs \\
\hline Prasad & 2016 & $\begin{array}{l}\text { All the } 16 \text { government ministries have adopted the } \\
\text { NPSAS in Nepal. This is a cash based form of IPSASs. }\end{array}$ \\
\hline Ijeoma & 2014 & $\begin{array}{l}\text { The central government of Pakistan has adopted a cash } \\
\text { form of IPSASs. The adoption process to other public } \\
\text { sector entities is ongoing in pashed out approach. }\end{array}$ \\
\hline \multirow[t]{2}{*}{ ACCA } & 2018 & $\begin{array}{l}\text { Unreliable data availed without the set out time and } \\
\text { inconsistency in reporting are the major drawbacks } \\
\text { hindering IPSASs implementation in Pakistan. }\end{array}$ \\
\hline & & $\begin{array}{l}\text { Bangladesh is the process of implementing a cash form of } \\
\text { IPSASs. }\end{array}$ \\
\hline Senarath and Ukwate & 2018 & $\begin{array}{l}\text { A } 10 \text { IPSASs Sri-Lankan approach is still being } \\
\text { implemented and adopted in Sri Lanka. However, the } \\
\text { government did not put it mandatory for public entities to } \\
\text { adopt the system. }\end{array}$ \\
\hline Mnif and Gafsi & 2017 & $\begin{array}{l}\text { Late submission of accounting documents to auditing } \\
\text { bodies is the main setback of adopting IPSASs in } \\
\text { Bangladesh. }\end{array}$ \\
\hline Hasan, Rose, Khair & 2015 & Use of different IPSASs forms hinders comparability \\
\hline
\end{tabular}




\section{International Public Sector Accounting Standards (IPSAS)}

Last few decades have shown that many courtiers have engaged in reform and modernization of the government accounting system. Development in the financial information system is the main inclined of these reforms (Christiaens et al., 2015) .The basic idea of these reforms tally with the concept of New Public Management (Becker et al., 2014). NPM is managerial thought, based on ideology to bring private practice into public sector (Hood, 1991). Public sector reforms widespread around the world under ideology of New Public Management (NPM), International organization such as World Bank, UNDO and IMF are the main promoters for dissemination of these reforms specially in developing countries (Hood, 1991). Public financial management can be improved by adoption of international public sector accounting standards (IPSAS) for financial reporting (PWC, 2013). Diversity in public financial information system and compliance with IPSAS created a need for harmonization in public sector accounting system ,thus IPSAS have become the international reference for the development of public sector accounting systems worldwide (Christiaens et al., 2015).

International Public Accounting Standards were instituted with the intention of modernizing public sector financial reporting. Issued and revised by the International Public Sector Accounting Standards Board (IPSASB), the standards are based on IFRS for application by public sector entities across the world (Pacter, 2014).

According to Majid and Adam (2015), the objective of financial reporting is to communicate the financial status of an enterprise for an informed decision making process. Financial information is useful when it is presented in a comparable, verifiable and understandable version. Government entities are obliged to fulfill the stewardship function by publicizing audited comparisons of the actual utilization of the public resources in accordance with the forecasted budget. The process used in the design and implementation of a budget is a measure of its accountability (De Luca and Prather, 2018). IPSAS standards are supported by a strong governance framework, quality principles, and a credible regulatory framework.

As such, adoption of the standards enables greater comparability of financial information by organizational stakeholders, motivation by investors to invest in foreign countries, a reduction in the overall cost of capital, improved economic growth and improved allocation of resources by the public institutions. IPSAS governs budgeting of assets and liabilities, revenues, expenditure and encumbrances and obligations on public business entities (Ijeoma and Oghoghomeh, 2014).

A research by Jayasinghe, Nath and Othman (2015) established a strong correlation between investor's confidence and the quality of public financial statements thus contributing to a nation's growth and financial stability.

IPSAS standards support the accrual-basis accounting method which means that expenses are reported on the income statements when earned and expenses recorded when used. As such, it is possible to match the budgeted amounts and actual amounts that project when implementing the budget. The standards provide for disclosures that clearly explain the differences between the budgeted and actual amounts (Dissanayake, 2017). This information helps in demonstrating the efficiency and effectiveness of the public entity in management of funds and provision of services. Investors are therefore suited to make informed choices based on the statements. In addition, the government is also positioned to make suitable decisions that are based on resource allocation thus improving transparency and accountability.

IPSAS allows for economic analysis by offering information pertaining to attainment and use of resources in accordance to the legally adopted budget, compliance of the entities with instituted legislations; allocation of the resources and outcomes that are related to performance indicators (Christiaens et al, 2015).

\section{Adoption of IPSAS in South Asia}

Several nations in South Asia initiated the financial management reforms in the public sector post the 1990s Global Financial Crisis (Sukmadilaga, Pratama, and Mulyani, 2015). The financial incentives offered by IMF and World Bank to fund the changes were conditional on reforms including the acceptance of accrual-based accounting. However, countries such as Nepal and Bangladesh that have already implemented the financial standards in line with the cash-based IPSAS standards are yet submit to the accrual-based reporting.

In India for instance, the government is yet to set a timeline for acceptance of IPSAS standards (Krishnan, 2016). In an article published by Ombati and Shukla (2018), the authors observed that although accrual disclosures are made in the country's public financial statements, the dominant method is a cash-based accounting. In Pakistan, most of the cash-based accounting is aligned with cash-based IPSAS framework which is applied by the national government. 
Sri Lanka on the other hand initiated a phased strategy to IPSAS implementation such that more than 10 Public Sector Accounting Standards that are equivalent to IPSAS have been issued. However, the standards are not yet mandatory with the implication being that not all public financial statements comply with the guidelines. The government had earlier announced that at least 21-IPSAS compliant standards would be documented for implementation by the close of 2012 but the goal is yet to be achieved (Senarath and Ukwate, 2015, ACCA, 2018).

In Nepal, the cash-based public sector financial reporting standards that conform to IPSAS guidelines were adopted for use by all public departments in 2009. The implementation process is ongoing and according to Adhikari et al. (2015), challenges such as lack of trained personnel and low stakeholder engagement have derailed the progress. Notably, the actual benefits of applying accrual accounting can be termed as part of the wider finance reform in the public sector thus serving as a mechanism to offer high quality financial reporting (PWC, 2013). The result is an improvement in operational and service outcomes that contribute to long-term sustainability of public sector financing.

A gap analysis by the World Bank was conducted in eight South Asian nations namely Bangladesh, Afghanistan, Bhutan, India, Maldives, Pakistan, Nepal, Sri lank and Bhutan to compare the use of public sector accounting standards practices to international guidelines. With regards to the accounting function, the authors established that one nation was using the cash-basis IPSAS by the close of 2009 (World Bank, 2011). By March 2010, several of the countries had progressed to the cash-based IPSAS accounting though none of the public entities was in full compliance to the standards (World Bank, 2011). In a related study Ali and Ahmed (2017) observed that no South Asia government showed the cash receipts and payments for public funds controlled by the entity in the preparation of financial statements. Only the central governments and agencies accounts presented the receipts. Although most of the governments are concerned about shifting to accrual-basis accounting, Ali and Ahmed (2017) noted that the initiative is long-term. Notable from the World Bank (2011) gap analysis is the fact that most of the governments in the eight nations have started to professionally develop the accounting staff through qualifications that conform to International Education Standards. However, much remains to be done in improving the capacity of the professionals to realize the skills and expertise needed to successfully implement the IPSAS policies.

Nurunnabi (2017) established that every government in South Asia is a member of the International Association of Supreme Audit Institutions (INTOSAI), and all the Supreme Audit Institutions (SAI) for individual nations have adopted INTOSAI standards. None of the SAIs practices auditing functions in the prescribed independence given that they depend on the government to offer funding incentives. In the report by the World Bank (2011), the institution applauded the SAIs for the move towards computerized working papers and techniques that are critical in enhancing quality and efficiency. The public sector auditing function is independent of the accounting department and as such, application of IPSAS influences the reporting process (El Firjani and Faraj, 2016).

The findings by World Bank (2011) further observed that only in one of the eight South Asian nations that the finance law provides particulars for international standards for public sector accounting and reporting. In the rest of the countries, either the Controller General of Accounts or the Auditor General has the power and authority to design and document accounting standards for the general government entities. World Bank recommended for government sectors in South Asia to espouse IPSAS for accounting and the prevailing accounting and finance laws, and specify IPSAS as part of the model for public sector reporting.

The findings on the adoption of IPSAS in South Asian nations can be categorized into; statement of cash receipts and payments, accounting policies and notes, budget and actual amounts, and financial statements.

The requirement for the cash-based IPSAS is that a statement of cash receipts and payments is prepared within three and six months after the end of the year. In a study by Javed and Zhuguan (2018), the authors noted that most of the South Asian nations are already reporting the statement of cash receipts and payments in the format stipulated by IPSAS. In addition, the cash-basis IPSAS requires the accountant to provide various notes disclosures including the specific accounting policies. Most of the countries have adopted the method.

Public entities should include a comparison of the budget estimates and actual amounts spent along with explanations for the variances. The reason for this requirement is to help public entities to meet their accountability obligations, enhance transparency, and compliance. Notable from the study by Mishra (2015) is that most of the South Asian nations have been preparing budget realization statements in accordance with the cash-basis IPSAS.

IPSAS further provides for the preparation of financial statements that incorporate the main government ministries and agencies and all the entities that are under its control (Augusto, 2018). As such, in preparation of the statement of cash receipts and payments, all the cash receipts, payments, and cash balances of the controlled entities should be 
consolidated. The research by World Bank (2011) established that the coding structure of the charts in majority of the South Asian nations makes it challenging to compile financial information at the national level in another level other than the budget basis.

\section{Adoption Challenges}

PWC (2013) collected survey data of 140 nations to understand the adoption of IPSAS across nations. The study observed a great diversity in accounting practices; a shift towards accrual accounting in most developing nations, and; that most budgets are constructed and implemented on a cash basis. In addition, through the online survey, it was determined that accounting for fixed assets, use of accrual concepts, and disclosure provisions tend to be the major impactful areas. According to PWC (2013) and Vasicek and Gorana (2014), it takes an average of three years for an entity to transit to accrual-based IPSAS. The reason for the long period as noted by Laswad and Redmayne (2015) is that the change is more than an accounting exercise but a transformation of the public entity function which subsequently impacts the entire organization. The implication of these observations is that implementing the IPSAS framework is challenging to most government entities.

\subsection{Bangladesh}

The government utilizes the cash-based IPSAS system and the responsibility for setting accounting framework is with the Auditor General and Comptroller (World Bank, 2011). The challenge faced by Bangladesh is with respect to timeliness of financial reporting (Mnif and Gafsi, 2017). In an article by Mnif and Gafsi (2017), the author observed that there is a significant delay in production of the documents needed for the reporting process with most of them being submitted late to the relevant institutions. In addition, the documents are not publicly available for scrutiny. For instance, the self-accounting entities such as Defense and Railways submit the documents late thus delaying the process of preparing the financial statements. The Defense of Railways delay to report their transactions to Controller General of Accounts thus disrupting the entire process.

Another challenge faced by Bangladesh is the limitation enhanced by separate accounting systems using by ministry and other government entities thus compromising the overall quality and effective implementation of the IPSAS (Hasan, Rose, Khair, 2015). Delay in the provision of the reports needed to produce reports and limitations of the different accounting systems are significant challenges that may take years to overcome.

\subsection{India}

As documented by Asian Development Bank, Abraham (2013) reiterated that India utilizes the cash-basis of accrual accounting with a limited accrual disclosures provided for in the financial statements. The government of India reported that implementation of IPSAS across the various entities is likely to take close to 12 years and a project team would be instituted to ensure full political buy-in (Abraham, 2013). The first challenge faced by India is the difference in readiness by the entities within Indian government and other public entities (Krishnan, 2016). Scarcity of information on assets and liabilities across many public entities in India, the delay in the formulation of a project management pilot studies, lack of appropriate accounting policies and charts, and a map to stipulate a timetable for the new processes have delayed the adoption of the IPSAS standards in India. According to Mirosea, Boolaky, and Signh (2017), decisions on information technology support are required to support accrual-based accounting. In addition, restructuring of the organization, determination of the pilot implementation sites, and a thorough execution plan have not be adequately designed and initiated to support the process thus making it a challenge for the accounting function to adopt IPSAS.

\section{$6.3 \mathrm{Nepal}$}

According to Adhikari (2017), Nepal Accounting Standards Board designed and published the Nepal Public Sector Accounting Standards (NPSAS) which are similar to cash-based IPSAS. NPSAS provide for mandatory and non-mandatory sections for enhanced disclosures. The government approved the application of NPSAS in 2009 with the support of a steering committee. Roll-out of the process took three years after which 16 financial statements from 16 public entities were submitted to the Auditor General for evaluation (Prasad, 2016).

Some of the notable challenges faced by the government in the implementation process include weak staff capacity, laxity by some of the stakeholders during the change, lack of skilled and experienced staff, lack of adequate stakeholder engagement, and inadequate change management processes to allow the stakeholders accept the reforms and take responsibility of the implementation process. In addition, difficulties in collecting data that is necessary for the disclosure of third party information limit further progress (Prasad, 2016). Legislation to pressure entities to adopt IPSAS is critical. 


\subsection{Pakistan}

The country has made steps in the adoption process by aligning cash-based accounting system with cash-basis IPSAS (Ijeoma, 2014). Transformation in Pakistan began with the design and implementation of the New Accounting Model (Ijeoma, 2014). The program continues to be adopted through a phased-out method. The challenges faced by the nation in the adoption process include: reliability of the data provided by the various entities, completeness and timeliness of the information, and inconsistencies in recognizing and recording the financial transactions (ACCA, 2018). The accounting staff is not adequately trained to adapt to the process in each of the phases thus making it difficult to standardize the process. The government is yet to integrate the budgeting and accounting standards in a comparable manner and as such, it is difficult for stakeholders to hold specific entities for the manner in which they spend public resources.

\subsection{Sri Lanka}

Senarath and Ukwate (2015) follow a phased-out approach towards the implementation of IPSAS. Given that adoption of the 10 Sri Lanka Public Sector Accounting Standards (SLPSAS) which are an equivalent of IPSAS is not compulsory, most of the public entities are yet to comply with IPSAS. The non-mandatory nature of the adoption process with respect to the 10 SLPSAS makes it challenging for the auditor general to oversee the implementation process since entities are at different stages of the execution process.

\section{Theoretical Contribution and Implication of the Research to Practice}

The findings on the adoption process of IPSAS in South Asian nations identified the challenges experienced in adopting IPSASs as well as the extent to which it has been adopted. These countries need to take one directional approach instead of what is currently happening on the ground (multi-directional approach) yet they are facing similar setbacks. This will ensure they implement a harmonized public accounting system based on IPSASs since this is a regional block. Identified challenges have now been brought to light and can be addressed for a smooth adoption of IPSASs.

\section{Conclusion}

The Asia Crisis of 1990s compelled public entities to embark on financial management reforms. However, funding for the implementation process from donors such as IMF and World Bank was conditional. Donors required the countries to initiate public finance management transformations, including the adoption of accrual accounting standards based on IPSAS. Study findings show that Nepal, Bangladesh, Pakistan and Sri Lanka have already adopted standards that align to the cash-basis IPSAS though no formal commitment to adopting the accrual-based IPSAS has been suggested while India is still setting up timeframe for the IPSASs adoption. The most common challenges faced by nations in South Asia in the adoption of IPSAS standards include lack of experienced staff, inadequate change management structures, failure by the governments to institute professional committees to oversee the reforms, and inconsistencies in the adoption process by the individual public entities. The study recommends the integration of International Education Standards into the recruitment, selection and development of staff to ensure workers are equipped with the required skills and experience to transit through the implementation process. All South Asian governments should put it mandatory for all government entities to adopt IPSASs and the approach used should be similar across these governments since this is a regional block experiencing similar drawbacks in the adoption of the standards.

\section{Limitation and Future Research}

This research is limited on literature review method, without questioner survey, complete interview with the respondent, further research may use other research methods, such as interview, questioners, group discussion that can be used to obtain two-way communication with the subject and get honest answers to the subject.

\section{References}

Abraham, C. (2013). Municipal Accounting Reforms in India: An Implementation Guide.

ACCA. (2018). IPSAS Implementation: Current Status and Challenges. Retrieved from https://www.accaglobal.com/content/dam/ACCA_Global/Technical/pubsect/pi-IPSAS-implementation-currentstatus-and-challenges.pdf

Adhikari, P. (2017). Public sector accounting practices and reforms in Nepal. The Routledge Handbook of Accounting in Asia, 192. https://doi.org/10.4324/9781315641867-18 
Adhikari, P., \& Mellemvik, F. (2010). The adoption of IPSASs in South Asia: A comparative study of seven countries. In Research in Accounting in Emerging Economies (pp. 169-199). Emerald Group Publishing Limited. https://doi.org/10.1108/S1479-3563(2010)0000010012

Ali, M. J., \& Ahmed, K. (2017). Determinants of accounting policy choices under international accounting standards: Evidence from South Asia. Accounting Research Journal, 30(4), 430-446. https://doi.org/10.1108/ARJ-02-2015-0020

Augusto, S. (2018). The impact of International Public Sector Accounting Standards (IPSAS) on financial reporting quality in public sector: case study Rushinga Rural District Council.

Becker, D. S., Tobias Jagalla, \& Peter Skaerbeak. (2014). The Translation of Accrual Accounting and Budgeting and the Reconfiguration of Public Sector Accountants' Identities. Critical Perspectives on Accounting, 25(4-5), 324-338. https://doi.org/10.1016/j.cpa.2013.05.004

Brusca, I., Caperchione, E., Cohen, S., \& Rossi, F. M. (Eds.) (2016). Public sector accounting and auditing in Europe: The challenge of harmonization. Springer.

Christiaens, J., Vanhee, C., Manes-Rossi, F., Aversano, N., \& Van Cauwenberge, P. (2015). The effect of IPSAS on reforming governmental financial reporting: An international comparison. International Review of Administrative Sciences, 81(1), 158-177. https://doi.org/10.1177/0020852314546580

De Luca, F., \& Prather-Kinsey, J. (2018). Legitimacy theory may explain the failure of global adoption of IFRS: the case of Europe and the US. Journal of Management and Governance, 1-34. https://doi.org/10.1007/s10997-018-9409-9

Dissanayake, T. (2017). The diffusion of new public financial management innovation in developing countries: evidence from Sri Lanka.

El-Firjani, E. R., \& Faraj, S. M. (2016). International Accounting Standards: Adoption, Implementation and Challenges. In Economics and Political Implications of International Financial Reporting Standards (pp. 231-250). IGI Global. https://doi.org/10.4018/978-1-4666-9876-5.ch011

Hasan, M., Rose, J., \& Khair, S. (2015). Background paper for the 7th five year plan of the government of Bangladesh: Governance and justice.

Hood, C. (1991). A Public Management for all Seasons?. Public Administration, 69(1), 3-19. https://doi.org/10.1111/j.1467-9299.1991.tb00779.x

Hopper, T., Lassou, P., \& Soobaroyen, T. (2017). Globalisation, accounting and developing countries. Critical Perspectives on Accounting, 43, 125-148. https://doi.org/10.1016/j.cpa.2016.06.003

Ijeoma, N. B. (2014). The impact of international public sector accounting standard (IPSAS) on reliability, credibility and integrity of financial reporting in state government administration in Nigeria. International Journal of Technology Enhancements and Emerging Engineering Research, 2(3), 2347-4289.

Ijeoma. N. B., \& Oghoghomeh, T. (2014). Adoption of international public sector accounting standards in Nigeria: Expectations, benefits andchallenges. Journal of Investment and Management, 3(1), 21-29. https://doi.org/10.11648/j.jim.20140301.13

Javed, M., \& Zhuquan, W. (2018). Analysis of Accounting Reforms in the Public Sector of Pakistan and Adoption of Cash Basis IPSAS.

Jayasinghe, K., Nath, N. D., \& Othman, R. (2015). The Public Sector Accounting, Accountability and Auditing in Emerging Economies: Insights, Gaps and Some New Ways Forward. In The Public Sector Accounting, Accountability and Auditing in Emerging Economies (pp. 1-6). Emerald Group Publishing Limited.

Kara, E. (2012). Financial Analysis in Public Sector Accounting. An Example of EU, Greece and Turkey. Eur. J. Sci. Res., 69(1), 81-89.

Krishnan, S. (2016). IFRS and IPSAS convergence in India-transnational perspectives. Doctoral dissertation, Manchester Business School.

Laswad, F., \& Redmayne, N. B. (2015). IPSAS or IFRS as the Framework for Public Sector Financial Reporting? New Zealand Preparers' Perspectives. Australian Accounting Review, 25(2), 175-184. https://doi.org/10.1111/auar.12052 
Majid, J. A., \& Adam, N. C. (2015). Resistance to Institutional Change through Decoupling. Mediterranean Journal of Social Sciences, 6(4), 531.

Mirosea, N., Boolaky, P., \& Singh, K. (2017). The Determinants of Accounting Harmonisation in Indonesia Municipalities/Cities. In International Conference on Accounting and Finance (AT). Proceedings (p. 117). Global Science and Technology Forum. https://doi.org/10.5176/2251-1997_AF17.62

Mishra, J. K. (2015). Study of public financial management systems for two Asian regional groups. OECD Journal on Budgeting, 14(3), 1-25. https://doi.org/10.1787/budget-14-5jrw9czdg326

Mnif Sellami, Y., \& Gafsi, Y. (2017). Institutional and Economic Factors Affecting the Adoption of International Public Sector Accounting Standards. International Journal of Public Administration, 1-13.

Mustapha, M., Ismail, K. N. I. K., \& Ahmad, H. N. (2017). Contingency For Financial Reporting Quality in the Public Sector Under Cash-Basis IPSAS: A Conceptual Approach.

Nurunnabi, M. (2017). Auditors' perceptions of the implementation of International Financial Reporting Standards (IFRS) in a developing country. Journal of Accounting in Emerging Economies, 7(1), 108-133. https://doi.org/10.1108/JAEE-02-2015-0009

Ombati, R., \& Shukla, A. (2018). Analyzing the problems with the current adoption of IFRS in the companies among India, China, Germany, Russia and Kenya. Accounting, 4(1), 29-40. https://doi.org/10.5267/j.ac.2017.3.002

Pacter, P. (2014). Global accounting standards-From Vision to reality. The CPA Journal, 84(1), 6.

Prasad, R. (2016). Presentation: IPSAS Implementation in Nepal Current Status, Challenges and Way Forward.

PWC (2013). Towards a New Era in Public Accounting and Reporting. Retrieved from https://www.pwc.com/gx/en/psrc/publications/assets/pwc-global--ipsas-survey-government-accounting-and-rep orting-pdf.pdf

Senarath Yapa, P. W., \& Ukwatte, S. (2015). The New Public Financial Management (NPFM) and Accrual Accounting in Sri Lanka. In The Public Sector Accounting, Accountability and Auditing in Emerging Economies (pp. 7-50). Emerald Group Publishing Limited.

Sukmaldilaga, C., Pratama, A., \& Mulyani P. (2015). Good governance implementation in public sector: Exploratory analysis of government financial statements disclosures across ASEAN Countries. Procedia - Social and Behavioral Sciences, 211, 513-518. https://doi.org/10.1016/j.sbspro.2015.11.068

Vašiček, V., \& Gorana, R. (2014, January). IPSAS translation and publishing: the importance for financial reporting. In 15. Medunarodni simpozij: PRIORITETI ZA BiH.

World Bank. (2011). Public Sector Accounting and Auditing in South Asia: A comparison to International Standards. Retrieved

from http://crossasia-repository.ub.uni-heidelberg.de/3644/1/Public\%20Sector\%20Accounting\%20South\%20Asia.pd $\mathrm{f}$

Yegidis, B. L., Weinbach, R. W., \& Myers, L. L. (2017). Research methods for social workers. Pearson. 